Windha

Widyastuti ${ }^{1}$

1 Program Studi DIII Keperawatan, STIKES

Muhammadiyah Pekajangan, Jl.Raya

Ambokembang No.8, Kabupaten Pekalongan,

Kode Pos 51 172, Indonesia

E-mail: windasetiadi@gmail.com

\title{
Otonomi Wanita dan Pemanfaatan Antenatal Care (ANC) pada Primigravida Remaja di Daerah Pedesaan, Jawa Tengah
}

Info Artikel:

Masuk : 19 Januari 2017

Revisi : 29 April 2017

Diterima : 24 Mei 2017

DOI Number : 10.18196/ijnp.1258

\section{ABSTRAK}

Remaja hamil dengan status pernikahan dan primigravida, menjadikan remaja rentan selain dari kehamilan resiko tingginya, juga dengan kecenderungan rendahnya kemampuan pengambilan keputusan di keluarganya. Rendahnya otonomi ini cenderung mempengaruhi pemanfaatan ANC mereka. Studi deskripsi korelasi ini bertujuan menguji hubungan antara otonomi wanita dan pemanfaatan ANC, yang dilakukan dari bulan September sampai Oktober, 2015, pada 85 primigravida remaja yang menikah dengan usia kehamilan $>28$ minggu, di seluruh Puskesmas Kabupaten Pekalongan, melalui analisis Chi Square. Hasil studi menunjukkan 31,8\% remaja tidak adekuat dalam memanfaatkan ANC. Hal ini dihubungkan dengan indeks otonomi wanita keseluruhan (p-value $\left.=0.013, X^{2}=6.168\right)$, terutama untuk dimensi familial health care decision making power $\left(\mathrm{p}\right.$-value $\left.=0.000, \mathrm{X}^{2}=31.264\right)$. Hasil ini menunjukkan pentingnya remaja memiliki kekuatan pengambilan keputusan dalam keluarga terutama selama kehamilannya, ini dipengaruhi pula oleh suami dan keluarga yang tinggal satu rumah. Direkomendasikan deskripsi Otonomi wanita ini menjadi bahan dalam konsultasi pernikahan kepada remaja dan keluarga.

Kata Kunci: ANC, Kehamilan, Otonomi, Primigravida, dan Remaja.

Adolescence, ANC, Autonomy, Pregnancy, and Primigravida

\section{ABSTRACT}

Pregnant adolescents with marital status and primigravida, making adolescent vulnerable apart from high risk pregnancies, as well as the low propensity of decision-making power in their family. This low autonomy tends to affect their ANC utilization. This correlation study aims to examine 


\section{NURSING PRACTICES}

the relationship between women autonomy and ANC utilization, conducted from September to October, 2015, among 85 married teenage primigravida, gestational age> 28 weeks, across Pekalongan District, through Chi Square analysis. The results showed that $31.8 \%$ of adolescents had inadequate ANC utilization. It related to the overall women autonomy index $(\mathrm{p}$-value $=0.013, \mathrm{X} 2=6.168)$, especially for familial dimension of health care decision making power $(p$-value $=0.000, X 2=31.264)$. Results indicate the importance of women autonomy among married adolescents especially during pregnancy, that is influenced by husband and family who live with them. Thus, this woman's autonomy should include in wedding consultations to teenagers and families.

Keywords: Adolescence, ANC, Autonomy, Pregnancy, and Primigravida.

\section{PENDAHULUAN}

Kehamilan remaja masih menjadi masalah utama di dunia yang berdampak baik pada sistem pelayanan kesehatan maupun di kehidupan sosial. Prevalensi kehamilan remaja masih cukup tinggi terutama di ASIA, salah satunya di Indonesia (WHO, 2007). Hal tersebut dibuktikan dengan sebuah survei di Indonesia pada tahun 2012 yang menunjukkan adanya peningkatan jumlah remaja yang melahirkan, dimana lebih banyak terjadi di daerah pedesaan (BPS, BKKBN, Kemenkes, dan ICF Internasional. 20 I3). Data dari pemerintahan provinsi Jawa Tengah sendiri, yang merupakan daerah dengan populasi terbesar di Indonesia, menunjukkan jumlah ibu usia remaja yang cukup besar, dengan angka melebihi dari target, 25,9 per I,000 perempuan (Dinas Kesehatan Provinsi Jawa Tengah, 2012).

Pada dasarnya kehamilan diusia remaja merupakan kehamilan beresiko tinggi yang dapat membahayakan baik bagi ibu atau pun bayinya (Iklaki, Inaku, Ekabua, Ekanem \& Udo, 20I2). Remaja juga dimungkinkan tidak dapat merawat kehamilannya dengan baik, dikarenakan adanya interupsi tugas perkembangan pertumbuhannya, dan rendahnya pengalaman karena sebagian besar dari mereka merupakan primigravida (Rohan, dan Siyoto, 20 I3). Pada dasarnya, resiko pada kehamilan tersebut dapat dicegah dengan ketepatan dan kesesuaian dalam kunjungan pemeriksaan kehamilan atau biasa disebut dengan Antenatal Care (ANC) (WHO, 2007).

Penelitian terdahulu menunjukkan bahwa remaja yang hamil, terlebih di daerah pedesaan cenderung mempunyai kunjungan ANC yang tidak adekuat, seperti hasil studi dari Mufidah, Ummah dan Eko (2010) di Kabupaten Lamongan menunjukkan 66\% remaja memiliki ANC yang tidak adekuat, sedangkan Mawaddah dan Maulina (20 I I) di Kabupaten Deli Serdang Medan menemukan hanya 28,3\% remaja dengan ANC yang adekuat.. Hasil penelitian tersebut sesuai dengan wawancara pada studi pendahuluan di Kabupaten Pekalongan, dimana letak geografis sebagian besar daerahnya di area pedesaan. Wawancara pada bulan Agustus 20I4, di peroleh $60 \%$ dari ibu hamil usia remaja memiliki kunjungan ANC yang tidak adekuat.

Selaras dengan studi pendahuluan tersebut, salah satu studi di Indonesia menunjukkan hambatan remaja dalam memanfaatkan pelayanan kesehatan, khususnya di daerah pedesaan, yaitu status pernikahan yang menempatkan remaja pada batasan-batasan di kehidupan rumah tangganya. Budaya yang ada di Indonesia sendiri, menghadapkan ibu muda pada rendahnya kekuatan otonomi di lingkungan keluarga (Utomo dan Utomo, 20 I3).

Remaja yang menikah cenderung mengalami perubahan tugas perkembangan secara tiba-tiba, dengan keterbatasan dukungan sosial di lingkungan keluarga, dan adanya tanggungjawab terhadap keluarga tanpa mempunyai kekuatan dalam pengambilan keputusan di dalamnya. Terlebih adanya bias gender, kehidupan sosial maupun ekonomi mereka pun terganggu yang akhirnya akan berdampak pada rendahnya pemanfaatan ANC (WHO, 2007). Gambaran ini terlihat saat studi pendahuluan penulis, dimana sebagian besar ibu hamil remaja tinggal bersama orangtua, dan tidak bekerja sehingga secara ekonomi bergantung pada suami ataupun orang tua mereka.

Di Indonesia, studi tentang otonomi wanita pada ibu hamil usia remaja yang telah menikah dan hubungannya dengan perilaku kesehatan dalam hal ini pemanfatan ANC belum tersedia. Sehingga penting dilakukan kajian untuk mengetahui hubungan antara otonomi dan pemanfaatan ANC pada ibu hamil usia remaja yang telah menikah di daerah pedesaan, Jawa Tengah. 


\section{METODE}

Studi deskripsi korelasi ini dilaksanakan pada 85 ibu hamil remaja sesuai definisi $\mathrm{WHO}$ dengan usia $<20$ tahun , primigravida dengan usia kehamilan $>28$ minggu yang berkunjung ke klinik ANC di seluruh Kabupaten Pekalongan. Penghitungan sampel merujuk pada penghitungan menurut Lwanga and Lemeshow (|99|) dengan confidence interval1.96, proporsi estimasi 0.33, and absolute error sebesar 10\%. Sampel diperoleh dengan teknik Systematic random sampling.

Pengumpulan data dimulai dari bulan September sampai Oktober, 2015, dengan 3 Research Assistant (RA) yang telah dilatih oleh peneliti untuk mengumpulkan data, dengan terlebih dahulu menjelaskan tujuan penelitian dan hak ibu hamil remaja selama berprartisipasi dalam penelitian melalui pembagian lembar informasi penelitian. Remaja yang menyetujui untuk berpartisipasi diminta untuk mengisi kuesioner dalam waktu 10 menit di ruang khusus dalam klinik ANC. Setelah menandatangani lembar persetujuan. Lembaga dewan review penelitian ini adalah Khon Kaen University dan ijin pelaksanaan penelitian dikeluarkan oleh Dinas Kesehatan Kabupaten Pekalongan pada bulan September, 2015.

Kuesioner penelitian ini berupa self-administered questionnaires, yang meliputi kuesioner untuk pengisian data demografi dan kuesioner modifikasi Otonomi wanita dari Haque, Rahman, and Mostofa (20 I I) dengan I I soal, meliputi Women's employment and economic decision-making autonomy (EEI), Family health care decision making autonomy (FFI), Freedom of movement autonomy (FMI) ,Women's attitude toward partner's violence(WAPVI). Pengukuran pemanfatan ANC sendiri menggunakan buku KIA yang dipegang oleh ibu. Kuesioner ditranslasi menggunakan Bahasa Indonesia dengan proses back translation oleh 3 bilingual translator. 4 professional experts di kesehatan reproduksi menguji skala validitas dari konten pertanyaan dalam kuesioner. Hasil dari analisa reliabilitas sendiri didapatkan cronbach's alpha 0.813 .

Chi- Square digunakan untuk menguji adanya hubungan antara Otonomi wanita dan kunjungan ANC pada ibu hamil remaja di daerah pedesaan, Jawa Tengah.
HASIL

Table 1 Data Demografi pada 85 Primigravida Usia Remaja di daerah pedesaan, Jawa Tengah

\begin{tabular}{|c|c|c|}
\hline Data & $\begin{array}{rr} & \text { Frequency } \\
\text { age } & (\mathrm{N}=85) \\
\end{array}$ & $\begin{array}{r}\text { Percent- } \\
\text { (\%) }\end{array}$ \\
\hline $\begin{array}{l}\text { Usia Kehamilan } \\
\text { (Bulan) }\end{array}$ & \multicolumn{2}{|c|}{$\begin{array}{l}x \square=32.15(S D=3.145) . M i n=28, \operatorname{Max} \\
=40\end{array}$} \\
\hline$<8$ bulan & 26 & 30.6 \\
\hline $8-9$ bulan & 42 & 49.4 \\
\hline$\geq 9$ bulan & 17 & 20 \\
\hline $\begin{array}{l}\text { Usia } \\
\text { (Tahun) }\end{array}$ & \multicolumn{2}{|c|}{$\begin{array}{l}x \square=18.0(S D=1.104) \cdot \operatorname{Min}=14, \operatorname{Max}= \\
19\end{array}$} \\
\hline
\end{tabular}

Remaja awal

\begin{tabular}{lcc}
$\begin{array}{l}(10-14) \\
\text { Remaja Tengah } \\
(15-16)\end{array}$ & 2 & 2.4 \\
$\begin{array}{l}\text { Remaja akhir } \\
(17-19)\end{array}$ & 5 & 5.9 \\
& 78 & 91.8 \\
\hline
\end{tabular}

\begin{tabular}{lcc}
\hline $\begin{array}{l}\text { Tingkat pendi- } \\
\text { dikan }\end{array}$ & & \\
SD & 55 & 64.7 \\
SMP & 25 & 29.4 \\
SMA & 5 & 5.9 \\
Penghasilan keluarga & & \\
(juta Rp/bulan/remaja) & & \\
$<1$ & 47 & 55.3 \\
I-2 & 34 & 40.0 \\
$2.1-5$ & 3 & 3.5 \\
$5.1-$ I0 & 1 & 1.2 \\
\hline Status Pekerjaan & & \\
Bekerja & & \\
Tidak Bekerja & 17 & 20 \\
& 68 & 80 \\
\hline $\begin{array}{l}\text { Perencanaan } \\
\text { Kehamilan }\end{array}$ & & \\
Direncanakan & 67 & 21.2 \\
Tidak diren- \\
canakan
\end{tabular}

\section{Pemanfaatan ANC}

Studi ini menunjukkan bahwa masih ada ibu hamil usia remaja yang mempunyai kunjungan ANC tidak adekuat (31.8\%). Ketidakadekuatan ini ditunjukkan dengan 


\section{NURSING PRACTICES}

keterlambatan pada kunjungan ANC pertama (> 14 minggu usia kehamilan) sesuai dengan Menteri Kesehatan Rl (20।2), dan tidak lengkapnya kunjungan, dimana hanya ada kunjungan di trimester I dan 2 saja. Terdapat 3 partisipan yang melakukan kunjungan ANC hanya pada trimester III, yang berarti pada awal kehamilan hingga trimester 2, partisipan tidak melakukan pemeriksaan kehamilan satu pun. Disisi lain, sebagian partisipan yang terlambat melakukan kunjungan ANC di trimester I, menambah kunjungan ANC mereka di usia kehamilan memasuki trimester III atau jika mereka berfikir waktu persalinan sudah semakin dekat (74.4\%).

\section{Otonomi wanita}

Penghitungan variabel ini mengadopsi penghitungan dari penelitian terdahulu, melalui metode konstruksi dari index perkembangan manusia (The human development index (United Nation Development Programme, 2005) (Haque, Rahman, Mostofa dan Zahan, 201 2). Pengkategorian otonomi wanita terbagi dalam otonomi wanita yang rendah dan tinggi.

Table 2 Frekuensi dan prsentase dari kekuatan pengambilan keputusan pada 85 primigravida usia remaja di Kabupaten Pekalongan

\begin{tabular}{ccc}
\hline & \multicolumn{2}{c}{ Frekuensi dan Prosentase (\%) } \\
\cline { 2 - 3 } Variabel & $\begin{array}{c}\text { Tidak memiliki } \\
\text { kekuatan } \\
\text { pengambilan } \\
\text { keputusan }\end{array}$ & $\begin{array}{c}\text { Memiliki } \\
\text { kekuatan } \\
\text { dalam } \\
\text { pengambilan } \\
\text { keputusan }\end{array}$ \\
\hline
\end{tabular}

EEI

I.

$68(80.0)$

$17(20.0)$

Apakah anda bekerja?

2.

$69(81.2)$

$16(18.8)$

Siapa yang

memutuskan

bagaimana

penghasilan

anda akan

digunakan?

3.

39 (45.9)

$46(54.1)$

Siapa yang

memberikan

keputusan

final menge-

nai pembeli-

an barang-ba

\begin{tabular}{lcc}
\hline & \multicolumn{2}{c}{ Frekuensi dan Prosentase (\%) } \\
\cline { 2 - 3 } Variabel & $\begin{array}{c}\text { Tidak memiliki } \\
\text { kekuatan } \\
\text { pengambilan } \\
\text { keputusan }\end{array}$ & $\begin{array}{c}\text { Memiliki } \\
\text { kekuatan } \\
\text { dalam } \\
\text { pengambilan } \\
\text { keputusan }\end{array}$ \\
\hline $\begin{array}{l}\text { rang rumah } \\
\text { tangga dalam } \\
\text { jumlah be- } \\
\text { sar? }\end{array}$ & \\
\hline $\begin{array}{l}4 . \\
\text { Siapa yang } \\
\text { memberikan } \\
\text { keputusan } \\
\text { final untuk } \\
\text { pembelian } \\
\text { barang-ba- } \\
\text { rang ke- } \\
\text { butuhan } \\
\text { sehari-hari? }\end{array}$ \\
\hline
\end{tabular}

FFI

5. $17 \quad(20.0)$ $68(80.0)$

Siapa yang memutuskan mengenai perawatan kesehatan bagi anda?

FMI

6. $9(10.6)$

76 (89.4)

Siapa yang

memberi

keputusan

final untuk

mengunjungi

keluarga

atau kera-

bat?

7.

II (I2.9)

74 (87.I)

Siapa yang

memberikan

keputusan

final untuk

pergi ke

puskesmas

atau rumah

sakit?

EEI : Women's employment and economic decision-making autonomy

FFI : Family health care decision making autonomy

FMI : Freedom of movement autonomy 
Table 3 Frekuensi dan prsentase dari sikap wanita terhadap kekerasan pasangan (WAPVI) pada 85 primigravida usia remaja di Kabupaten Pekalongan

\begin{tabular}{|c|c|c|}
\hline \multirow[b]{2}{*}{ Variabel } & \multicolumn{2}{|c|}{ Frekuensi dan Prosentase (\%) } \\
\hline & $\begin{array}{c}\text { Remaja yang } \\
\text { membenarkan } \\
\text { pemukulan istri }\end{array}$ & $\begin{array}{c}\text { Remaja } \\
\text { yang tidak } \\
\text { membenarkan } \\
\text { pemukulan istri }\end{array}$ \\
\hline \multicolumn{3}{|l|}{$\begin{array}{l}\text { Menurut pendapat } \\
\text { anda apakah } \\
\text { dibenarkan bagi } \\
\text { suami untuk } \\
\text { memukul istrinya } \\
\text { dalam situasi berikut } \\
\text { ini? }\end{array}$} \\
\hline $\begin{array}{l}8 . \\
\text { Ketika anda } \\
\text { meninggalkan } \\
\text { rumah tanpa } \\
\text { memberitahu } \\
\text { suami anda }\end{array}$ & $69(8 \mathrm{I} .2)$ & $16(18.8)$ \\
\hline $\begin{array}{l}9 . \\
\text { Ketika anda } \\
\text { bertengkar } \\
\text { dengan suami } \\
\text { anda }\end{array}$ & $80(94.1)$ & $5(5.9)$ \\
\hline $\begin{array}{l}\text { I0. Jika } \\
\text { istri mengab- } \\
\text { aikan anak- } \\
\text { anak dan } \\
\text { mengabaikan } \\
\text { hal-hal yang } \\
\text { penting bagi } \\
\text { janin }\end{array}$ & $70(82.4)$ & $15(17.6)$ \\
\hline $\begin{array}{l}\text { Il. Ke- } \\
\text { tika anda me- } \\
\text { nolak untuk } \\
\text { berhubungan } \\
\text { badan dengan } \\
\text { suami anda }\end{array}$ & $72(84.7)$ & $13(15.3)$ \\
\hline
\end{tabular}

Hasil studi yang dapat dilihat pada tabel 2 menunjukkan mayoritas ibu hamil remaja tidak mempunyai kemampuan untuk memutuskan sendiri bagaimana uang yang dimilikinya akan digunakan untuk kebutuhan keluarga (81.2\%) dan mereka tidak memiliki kekuatan untuk menentukan pembelian kebutuhan rumah tangga skala besar (45,9\%). Data lain dari otonomi wanita diketahui masih banyak remaja yang mengalami kendala dalam hal mengakses rumah sakit dan mengunjungi keluarga mereka (23,5\%).
Dalam kategori Sikap remaja terhadap kekerasan seperti ditampilkan dalam tabel 3, masih ada sejumlah besar remaja yang membenarkan pemukulan istri untuk beberapa alasan, seperti ketika mereka meninggalkan rumah tanpa menginformasikan kepada suami (18.8\%), atau jika mereka menyepelekan sesuatu yang itu baik untuk janinnya (17.6\%), atau pada situasi dimana mereka menolak melakukan hubungan seksual dengan suami (15.3\%).

Hasil studi otonomi wanita secara menyeluruh sendiri menunjukkan bahwa mayoritas dari remaja hamil yang tinggal di pedesaan di Indonesia mempunyai kategori otonomi wanita yang rendah (61.6\%), terutama pada pengambilan keputusan ekonomi wanita dengan hasil Otonomi pengambilan keputusan tentang pekerjaan dan ekonomi wanita (EEI) berkisar 80\%, sebaliknya, mayoritas mereka mempunyai kemampuan yang tinggi dalam memutuskan perawatan kesehatan mereka sendiri dengan hasil Otonomi dalam pengambilan keputusan tentang perawatan kesehatan keluarga (FFI) adalah 79.1\%, dan kebebasan mobilitas selama kehamilannya dengan hasil Otonomi dalam Kebebasan Bergerak/ Mobilitasi (FMI) sebesar $77.9 \%$.

Data dari analisis bivariat yang dipaparkan pun memperlihatkan bahwa semakin tinggi derajat otonomi wanita maka akan mampu meningkatkan perilaku kesehatan mereka salah satunya untuk memanfaatkan ANC dengan kunjungan secara adekuat ( $p$-value $\left.=0.013, X^{2}=6.168\right)$. Studi ini juga menunjukkan bahwa antara 4 dimensi yang ada di otonomi wanita, hanya otonomi pengambilan keputusan perawatan kesehatan keluarga (FFI) yang mempunyai hubungan dengan pemanfaatan ANC ( $p$-value $=0.000, \quad X^{2}=31.264$ ). Hubungan tersebut diperlihatkan dalam tabel berikut:

Tabel 4 Hubungan antara Otonomi wanita dan Pemanfaatan ANC pada 85 primigravida usia remaja di Kabupaten Pekalongan

\begin{tabular}{lcccc}
\hline & \multicolumn{4}{c}{ Pemanfaatan ANC } \\
\cline { 2 - 5 } \begin{tabular}{c} 
Dimensi $\begin{array}{c}\text { Otonomi } \\
\text { wanita }\end{array}$ \\
\cline { 2 - 5 }
\end{tabular} & $\begin{array}{c}\text { Adekuat } \\
(\mathbf{n}, \%)\end{array}$ & $\begin{array}{c}\text { Tidak } \\
\text { Adekuat } \\
(\mathbf{n}, \%)\end{array}$ & p-Value & $\boldsymbol{X}^{2}$ \\
\hline EEI & & & .215 & 1.540 \\
$\begin{array}{c}\text { Rendah } \\
(<\mathbf{0 . 5})\end{array}$ & $45(65.2)$ & $24(34.8)$ & & \\
\hline
\end{tabular}




\section{NURSING \\ PRACTICES}

\begin{tabular}{|c|c|c|c|c|}
\hline \multirow[b]{2}{*}{$\begin{array}{c}\text { Dimensi } \\
\text { Otonomi } \\
\text { wanita }\end{array}$} & \multicolumn{4}{|c|}{ Pemanfaatan ANC } \\
\hline & $\begin{array}{c}\text { Adekuat } \\
(\mathrm{n}, \%)\end{array}$ & $\begin{array}{c}\text { Tidak } \\
\text { Adekuat } \\
(\mathrm{n}, \%)\end{array}$ & $p$-Value & $X^{2}$ \\
\hline $\begin{array}{l}\text { Tinggi } \\
(\geq 0.5)\end{array}$ & $13(82.4)$ & $3(18.8)$ & & \\
\hline
\end{tabular}

\begin{tabular}{|c|c|c|c|c|}
\hline FFI & & & $.000 *$ & 31.264 \\
\hline $\begin{array}{l}\text { Rendah } \\
(<\mathbf{0 . 5}) \\
\text { Tinggi } \\
(\geq \mathbf{0 . 5})\end{array}$ & $\begin{array}{c}2(11.8) \\
56(82.4)\end{array}$ & $\begin{array}{l}15(88.2) \\
12(17.6)\end{array}$ & & \\
\hline $\begin{array}{l}\text { FMI } \\
\begin{array}{l}\text { Rendah } \\
(<0.5)\end{array} \\
\text { Tinggi } \\
(\geq 0.5)\end{array}$ & $\begin{array}{l}\text { II (6I.I) } \\
47(70.1)\end{array}$ & $\begin{array}{c}7(38.9) \\
20(29.9)\end{array}$ & .656 & .535 \\
\hline $\begin{array}{l}\text { WAPVI } \\
\qquad \begin{array}{l}\text { Rendah } \\
(<\mathbf{0 . 5}) \\
\text { Tinggi } \\
(\mathbf{0} . \mathbf{5})\end{array}\end{array}$ & $\begin{array}{l}\text { I3 (76.5) } \\
45(66.2)\end{array}$ & $\begin{array}{c}4(23.5) \\
23(33.8)\end{array}$ & .415 & .665 \\
\hline $\begin{array}{l}\text { Overall } \\
\text { Otonomi } \\
\text { wanita }\end{array}$ & $31(58.5)$ & $22(4 I .5)$ & $.013^{*}$ & 6.168 \\
\hline $\begin{array}{l}\text { Rendah } \\
(<0.5)\end{array}$ & $27(84.4)$ & $5(15.6)$ & & \\
\hline $\begin{array}{l}\text { Tinggi } \\
(\geq 0.5)\end{array}$ & & & & \\
\hline
\end{tabular}

*Significant level $0.05(p<0.05)$

EEI : Women's employment and economic decisionmaking autonomy

FFI : Family health care decision making autonomy

FMI : Freedom of movement autonomy

WAPVI : Women's attitude toward partner's violence

\section{PEMBAHASAN}

Ibu hamil remaja cenderung memiliki tingkat pendidikan yang lebih rendah dibandingkan remaja yang tidak hamil, sehingga status kehidupan sosial dan ekonomi mereka pun rendah, yang akhirnya berdampak pada perilaku kesehatan rendah (Fleming, 2015) Hal ini sesuai dengan hasil studi yang menunjukkan mayoritas ibu hamil usia remaja, hanya menyelesaikan pendidikan sebatas sekolah dasar, dan sebagian besar dari mereka tidak mempunyai pekerjaan. Konsekuensi dari hal tersbeut, lebih dari separuh remaja hamil hidup dengan pendapatan dibawah rata-rata minimal. Hasil penelitian ini sesuai dengan penelitian terdahulu di kota Manado dan Banyumas, Indonesia (Trisnawati \& Khosida, 2014; Ginting, dan Wantania, 20II). Studi di Thailand juga menunjukkan bahwa ibu hamil remaja cenderung memiliki pendapatan yang rendah sebagai akibat dari pendidikan yang rendah (Neamsakul, 2008). Survey di Indonesia (2012) sendiri menyebutkan masalah finansial merupakan hambatan pemanfaatan ANC pada usia remaja.

Terkait dengan perencanaan kehamilan, studi menunjukkan mayoritas dari ibu hamil remaja telah merencanakan kehamilan mereka setelah pernikahan. Hal ini berlawanan dengan penelitian sebelumnya yang telah dilakukan di Thailand dengan pendekatan Grounded theory dan Turkey, dimana kehamilan di usia remaja cenderung tidak direncanakan (Neamsakul, 2008; Sen, dkk, 2012). Adanya budaya pernikahan dini di Indonesia, mungkin menjadi alasannya, ditambah lagi menikah di Indonesia merupakan tahap yang harus dilalui untuk memperoleh keturunan, sehingga pasangan yang telah menikah diharapkan untuk dapat segera memperoleh keturunan, walaupun usia mereka masih di bawah umur (Ginting dan Wantania, 201 I; Situmorang, 2003).

Hasil studi juga menunjukkan kebanyakan partisipan merupakan remaja akhir (17-19 tahun), sesuai dengan studi di Kota Manado, Indoensia (Ginting dan Wantania, 201।), bahkan di negara berkembang lainnya seperti Filipina oleh Abecia, dkk (2010). Remaja akhir cenderung lebih matang perkembangannya, lebih mampu untuk berfikir secara rasional dan lebih dekat pada karakter usia dewasa, sehingga mereka lebih cenderung mempunyai kemampuan untuk memanfaatkan ANC dibandingkan dengan remaja awal seperti hasil studi yang menunjukkan pemanfaatan ANC sebesar 68.2\%. Namun demikian, angka ini masih tetap di bawah rekomendasi dari program kesehatan ibu dan anak dimana target dari pemanfaatan ANC adalah 95\% (BPS, BKKBN, Kemenkes, dan ICF Internasional. 2013).

Masih ada sejumlah remaja hamil yang tidak adekuat dalam memanfaatkan ANC (31.8\%). Rendahnya pemanfaatan ANC 
dianatara ibu hamil remaja, umum terjadi di berbagai negara berkembang, seperti halnya di Thailand (Manithip, Sihavong, Edin, Wahistrom, Wessel, 20II) dan Myanmar (Sein, 20 I2). Hal ini menempatkan remaja pada resiko komplikasi baik kehamilan atau pun komplikasi setelah persalinan, yang turut andil dalam peningkatan $\mathrm{AKI}$ atau pun $\mathrm{AKB}$ di Indonesia (Utomo, 2003)

Pada dasarnya, memilih tentang apa yang harus dilakukan selama kehamilan merupakan suatu bentuk pengambilan keputusan terpenting yang mungkin pernah remaja lakukan selama hidupnya. Remaja sendiri cenderung mempunyai kemampuan pengambilan keputusan yang rendah dalam menentukan sesuatu yang dianggapnya penting (Aruda, dkk, 2008). Hal ini dapat digambarkan dengan rendahnya otonomi wanita di kalangan remaja, seperti yang ditunjukkan dari hasil studi analisa deskriptif untuk otonomi wanita dimana 61.6\% remaja hamil mempunyai level otonomi yang rendah.

Konsep otonomi pada ibu hamil remaja terutama dengan status pernikahan, digambarkan dengan konsep otonomi wanita yang mencakup seluruh dimensi, seperti Otonomi dalam Kebebasan Bergerak/ Mobilitasi (freedom of movementautonomy (FMI)), Otonomi dalam Perawatan Kesehatan Keluarga (familial health care decision making autonomy (FFI)), Otonomi dalam pengambilan keputusan tentang pekerjaan dan ekonomi wanita (women's employment and economic decision making autonomy (EEI)), dan otonomi dalam sikap wanita terhadap kekerasan pasangan (women's attitude regarding partner's violence (WAPVI)) (Woldemicael, 2009).

Keempat dimensi tersebut telah diujikan di Bangladesh oleh Haque, Rahman, Mostofa, \& Zahan (20II) dengan design cross-sectional dimana diperoleh hasil ibu dengan ANC yang adekuat adalah mereka dengan otonomi wanita yang tinggi dalam indeks keseluruhan dimensi otonomi wanita $(p$ value $\leq .05 ;$ AOR, 1.64, 95\% Cl, I. 17-2.23). Temuan yang sama juga diperoleh di daerah pedesaan, di India Utara oleh Pallidakvath, Foss and Stones (2005), dengan hasil studi sejalan dengan temuan di Bangladesh, dimana remaja dengan indeks otonomi wanita secara keseluruhan yang besar cenderung memiliki pemanfaatan ANC yang adekuat ( $p=.013$ ).

Di negara-negara berkembang, mobilitas remaja putri cenderung terbatas, terlebih mereka yang telah menikah, dimana hal ini mempersulit mereka untuk mengakses pelayanan kesehatan (WHO, 2007). Survei di Indonesia menyebutkan bahwa wanita mempunyai hambatan yang besar untuk mengakses pelayanan kesehatan, terutama remaja, dimana mereka harus mendapatkan ijin dari suami atau keluarganya terlebih dahulu (BPS, BKKBN, Kemenkes, and ICF Internasional, 2013; WHO, 2007). Berlawanan dengan studi tersebut, hasil penelitian ini menunjukkan sebagian besar ibu hamil remaja mempunyai otonomi kebebasan bergerak/ mobilitasi (FMI) sebesar 77,9\%.

Studi ini menunjukkan tidak adanya hubungan antara FMI dan pemanfaatan ANC ( $p=$.465). Hasil tersebut berlawanan dengan studi sebelumnya, seperti studi di daerah pedesaan India (Mistry, Galal dan Lu, 2009). Hal ini mungkin terjadi karena sebagian besar partisipan adalah ibu rumah tangga yang mempunyai banyak waktu untuk melakukan kunjungan ANC yang biasanya dilakukan di pagi hari saat suami atau keluarga mereka masih bekerja, dan lagi, ANC biasanya diadakan melalui Posyandu yang lokasinya dekat dengan rumah mereka (Dinas Kesehatan Kabupaten Pekalongan, 2012).

Adanya keterlibatan remaja dalam pengambilan keputusan untuk kesehatan keluarga, turut meningkatkan kemungkinan untuk memanfaatkan pelayanan kesehatan melalui tersedianya dukungan suami selama kehamilannya, seperti halnya penelitian yang telah dilakukan di Bangladesh, dimana tingginya otonomi pengambilan keputusan tentang perawatan kesehatan keluarga (FFI) berhubungan dengan pemanfaatan ANC ( $p$ value $\leq .05$ ). (Haque dkk, 2012). Temuan tersebut juga didapatkan dalam studi ini, dengan $p=.000$.

Wanita yang memiliki kekuatan atau tingkat otonomi yang tinggi juga cenderung tidak setuju dengan pembenaran untuk kekerasan dalam rumah tangga. Oleh karena itu, adanya kekuatan otonomi wanita dapat mengurangi risiko kekerasan pada remaja, dimana remaja lebih rentan mengalami kekerasan dalam kehidupan keluarga (Fogel dan Woods, 2008; Haque dkk, 2008; Woldemicael, 2007). Kekerasan di kalangan remaja hamil mungkin terkait dengan adanya peran gender dimana status perempuan bergantung pada keterikatan mereka terhadap laki-laki, terlebih lagi dengan kurangnya pengalaman mereka dalam pengambilan keputusan keluarga menambah sulitnya situasi (WHO, 2007). Namun, 


\section{NURSING PRACTICES}

hasil studi ini menunjukkan bahwa remaja hamil yang tinggal di daerah pedesaan di Jawa Tengah memiliki risiko yang rendah untuk mengalami kekerasan dimana hasil analisis deskriptif menunjukkan bahwa mayoritas remaja hamil tidak setuju tindakan kekerasan dengan alasan apapun (79, I\%). Hal ini mampu meningkatkan perilaku kesehatan mereka, karena kemampuan remaja untuk mengelola kesehatan reproduksi mereka dapat dibatasi oleh kekerasan (Haque dkk, 2012; Fogel dan Woods, 2008).

Terkait dengan biaya yang harus dikeluarkan untuk mengakses ANC, remaja cenderung bergantung pada dukungan finansial dari suami atau keluarga (Ibu) karena rendahnya otonomi mereka, seperti pada hasil penelitian dimana mayoritas partisipan $(79,1 \%)$ tidak memiliki kekuatan dalam pengambilan keputusan ekonomi (EEI). Survei di Indonesia (2012) menyebutkan remaja memiliki hambatan finansial yang menjadi halangan dalam mengakses pelayanan kesehatan. Budaya di negara-negara berkembang memang menunjukkan laki-laki sebagai pengontrol keuangan, sehingga remaja kesulitan untuk membayar pelayanan kesehatan ataupun transportasi untuk pergi ke klinik ANC tersebut (Shimkada, Van, Porter dan Shimkada, 2007).

Rendahnya pengambilan keputusan finansial/ ekonomi wanita (EEI), sebagai efek dari patriarki sendiri mampu meningkatkan resiko perilaku kekerasan yang dapat dialami remaja, yang akhirnya berdampak pada perilaku kesehatan mereka (Haque dkk, 2012; WHO, 2007). Berlawanan dengan ini, uji chi-square menunjukkan tidak adanya hubungan antara pengambilan keputusan ekonomi wanita/finansial (EEl) dengan pemanfaatan ANC ( $p=.215)$. Hasil ini berlawanan dengan studi yang dilakukan di Bangladesh (AOR. I.56; 95\% Cl, 109-2.097) (Haque dkk, 20 I2).

Temuan tersebut dimungkinkan terjadi karena sebagian besar remaja tinggal bersama orang tua sehingga mengenai biaya perawatan kesehatan, remaja putri sangat bergantung pada anggota keluarga, terutama suami atau ibu mereka yang memberikan dukungan finansial (WHO, 2007; Haque dkk., 20l I). Hal ini diperkuat pula oleh studi terdahulu yang dilakukan di India, yang menjelaskan bahwa ketika suami, ibu mertua dan anak perempuan menyetujui pentingnya suatu kebutuhan akan kesehatan, hal itu akan ditangani dengan cepat (Baruan \& Kurz, 200I).

\section{KESIMPULAN}

Studi ini menunjukkan bahwa dengan mempunyai kekuatan dalam pengambilan keputusan pada remaja terutama dalam perawatan kesehatan keluarga mampu memberikan kesempatan kepada mereka untuk dapat memanfaatkan ANC secara adekuat selama kehamilannya. Dalam pengembangan kemampuan pengambilan keputusan tersebut, remaja mungkin membutuhkan bantuan atau persetujuan dari anggota keluarga untuk pemanfaatan perawatan kesehatannya, terlebih lagi, kekuatan ibu hamil remaja sendiri juga dipengaruhi oleh kekuatan kontrol dari suami. Oleh karena itu, pentingnya otonomi wanita disarankan dikomunikasikan kepada remaja dan keluarga ketika remaja menjalani konsultasi pernikahan.

\section{REFERENSI}

Abecia, A.R., Alamis, J., Bongcawil, S.M.D., Chio, R., Ledesma, K.K.I., Ricarte, A.M. (2010). Health-Seeking Behavior of Filipino Teenage Pregnant Women at Selected Barangays of Cagayan de Oro City. Nursing Research Journal, 2(1), 56-72.

Aruda, Mary M, et al.(2008). Early Pregnancy in Adolescents : Diagnosis, Assessment, Options, Counseling and Referral. Journal of Pediatric Health Care, 24(1), 4-13

Baruan, A \& Kurz, K.(2001). Reproductive health-seeking by married adolescent girls in Maharashtra, India. Reproductive Health Matters, 9(17), 53-62.

Dinas Kesehatan Kabupaten Pekalongan. (2012). Profil Kesehatan Kabupaten Pekalongan Tahun 2012. Pekalongan: Dinas Kesehatan Kabupaten Pekalongan Dinas Kesehatan Provinsi Jawa Tengah. (2012). Buku Profil Kesehatan Provinsi Jawa Tengah Tahun 2012. Retrieved on June, 6, 2015, from www.dinkesjatengprov.go.id

Fleming, dkk. Adolescent Pregnancy Guidelines.J ObstetGynaecol Can. 2015; 37(8):740-59

Fogel, I.C. \& Woods, F.N. (2008). Women's Health Care in Advanced Practice Nursing. Newyork : Springer Publising Company

Ginting, F \& Wantania, J. Pengetahuan, Sikap dan Perilaku Remaja yang Hamil Tentang Kehamilan Remaja di Manado. Buletin Idi Manado. 2011; 47-59

Haque, S.E., Rahman, M., Mostofa, G., \& Zahan., S. (2012). Reproductive Health Care Utilization among Young 
Mothers in Bangladesh : Does Autonomy Matter?. Women's Health Issues. 22(2), 171-180.

Iklaki, C. U., Inaku, J.U., Ekabua, J.E., Ekanem, E.L., \& Udo, A.E. (2012). Perinatal Outcome in Unbooked Teenage Pregnancies in the University of Calabar Teaching Hospital, Calabar, Nigeria. ISRN Obstet Gynecol, 2012, 1-5

Manithip, C., Sihavong, A., Edin, K., Wahistrom, R., \& Wessel, H. (2011). Factors Associated with Antenatal Care Utilization among Rural Women in Lao People's Democratic Republic. Maternal Child Health Journal, 15(8), 1356-1362.

Mawaddah Dan Maulina. (2011). Hubungan pengetahuan ibu hamil tentang antenatak care dengan jumla kunjungan antenatal care di Desa Laut Derdang Kecamatan Percut Setuan Kabupaten Deli Serdang Medan. Skripsi Tidak Diterbitkan. Medan: Universitas Sumatera Utara

Mistry, R., Galal, O., \& Lu, M. (2009). Women's Autonomy and Pregnancy Care in Rural India: A Contextual Analysis. Social Science \& Medicine, 69(6), 926-933

Mufidah, L., Ummah, F., \& Eko, D. (2010). Hubungan Usia Ibu Hamil Trimester 3 Dengan Keteraturan Antenatal Care K4 Di Bps Ny. S Desa Sidomukti Kecamatan Lamongan Kabupaten Lamongan. Surya, 1(V).

Neamsakul, W. (2008). Unintended Thai adolescent pregnancy: A grounded theory study. Ph.D Dissertation, Doctor of Philosophy in Nursing, Graduate Division, University of California, San Fransisco.

Pallikadavath, S., Foss, M., \& Stones, M.W. (2005). Antenatal care: Provision and inequality in rural north India. Social Science and Medicine. 59(6), 1147-1158.

Rohan, H. H, \& Siyoto, S. (2013). Buku Ajar: Kesehatan Reproduksi. Yogyakarta: Nuha Medika

Sen, E., Guneri, S.E., Yanikkerem, E., Hadimli, A., Kavlak, O., \& Sirin, A. (2012). Determination of Knowledge Requirements and Health Practices of Adolescent Pregnant Women. International Journal of Caring Sciences, 5(2), 171-175

Sein, K. K. (2012). Maternal health care utilization among ever married youths in Kyimyindaing Township, Myanmar. Matern Child Health J, 16(5), 1021-30.
Situmorang, A. (2003). Adolescent Reproductive Health in Indonesia. Retrived December, 13, 2015, from http:// pdf.usaid.gov/pdf_docs/Pnacw743.pdf

Statistics Indonesia (Badan Pusat Statistik-BPS), National Population and Family Planning Board (BKKBN), and Kementerian Kesehatan (Kemenkes-MOH), and ICF International. 2013. Indonesia Demographic and Health Survey 2012. Jakarta, Indonesia: BPS, BKKBN, Kemenkes, and ICF International.

Trisnawati, Y \& Khosidah, A. (2014). Permasalahan antenatal care (anc) pada kehamilan remaja di wilayah puskesmas karanglewas kabupaten banyumas. Akademi Kebidanan YLPP Purwokerto

Utomo, I.D. (2003). Adolescent reproductive health in Indonesia status, issues, policies and programs. The project is implemented by Futures Group International in collaboration withResearch Triangle Institute and the Centre for Development and Population Activities (CEDPA).

Utomo, I.D., \& Utomo, A. (2013). Adolescent pregnancy in Indonesia: A literature review. Australian Demographic and Social Research Institute

Woldemicael, G. (2007). Do Women with Higher Autonomy Seek More Maternal and Child HealthCare? Evidence from Ethiopia and Eritrea. Stockholm Research Reports in Demography, Department of Sociology, Demography Unit, Stockholm University.

Woldemicael G. (2009). Women's autonomy and reproductive preferences in Eritrea. Journal of Biosocial Science, 41(2), 161-181.

World Health Organization (WHO). (2007). Adolescent Pregnancy-Unmet Needs and Undone Deeds: A review of the literature and programmes: Issues in Adolescent Health and Development. Electronic Resources. Department of Child and Adolescent Health and Development. 